\title{
Toward integration of reading and service learning through an interdisciplinary program
}

\author{
Shun-yee Ho • Vivien Man-wai Lee
}

Received: 10 March 2011 / Revised: 20 July 2011 / Accepted: 31 August 2011/Published online: 17 September 2011

(C) The Author(s) 2011. This article is published with open access at Springerlink.com

\begin{abstract}
This study examined the effect of an interdisciplinary program of reading and service learning on the cognitive and affective development of university students in Hong Kong. As Nussbaum (1997) stated, literature plays a vital role in educating citizens of the world through its narrative imagination and its power of promoting understanding and empathy toward the life of others. Halstead and Pike (2006) also emphasized that art can foster reflection upon action and bring about change in behavior as a result of perspective change. In this study, 24 freshmen read literary works under the theme of children's welfare and explored issues related to the welfare of children worldwide. Their reflections on these materials were expressed in writing and in a presentation. In the following semester, the students participated in voluntary services within and outside Hong Kong. All students completed a questionnaire on their humanistic concerns and sense of global citizenship at the beginning and the end of the project. Results showed that students were conscious of their changes after joining the program and stated their growth in values and knowledge. The pre-post-t-test analysis suggested that students had made significant improvement in the following areas: (1) their attitude toward serving others, especially in their personal and social values; (2) their engagement in reading literary and nonfiction works which reflect social and moral issues of the world; (3) their attention to world affairs; (4) their concern for the underprivileged; and (5) awareness of their potential in helping the poor.
\end{abstract}

S. Ho $(\bowtie) \cdot$ V. M. Lee

Faculty of Education, The University of Hong Kong,

Pokfulam Road, Hong Kong

e-mail: hosya@hkucc.hku.hk
Keywords Reading - Literature - Service learning · Citizenship

\section{Introduction}

Young people in Hong Kong are apathetic about world affairs. A survey by the Chinese YMCA of Hong Kong (2010) using a random sampling method showed that only $30 \%$ of 2488 secondary students in Hong Kong paid attention to world news, and only $10 \%$ to different ethnic cultures. All the students were concerned about the problem of environmental protection, but only $22 \%$ of them acted to improve it. They might have thought that those issues were remote to them. Educators must be disappointed by the result of the survey. If young people are merely concerned about their own lives, how can we expect them to become informed, responsible citizens by playing an active role in local and global communities through utilization of knowledge, skills, and values? It is hoped that young citizens can acquire a richer understanding of themselves, the world, and humanity.

The cultivation of humanity has long been the tradition of Western liberal education. Reading is an important approach to enriching students' understanding of the human condition. Literary works and related non-literary materials not only provide an insight into the lives of others, but also stimulate moral thinking about values. As Nussbaum (1997) states, literature plays a vital role in educating citizens of the world through its narrative imagination that enables us to comprehend the motives and choices of people "different from ourselves." Narrative art, with its engaging formats, empowers us to see the lives of others with empathy and respect. Students can explore a wide range of themes and genres in fiction and nonfiction. 
Today, more educators advocate the use of multicultural books. Vacca and Vacca (2005) maintain that "through interactions with characters representing a variety of cultures, young people begin to view members of parallel cultures as individuals who are unique and yet have universal feelings and experiences." Literature therefore broadens students' horizons of life. They can learn about cultural heritages and ethical issues through the beauty, the emotions, and the thoughts in literature.

Artistic activity and response can enable students to change their attitudes and motivate them to take actions. Halstead and Pike (2006) emphasize that art can foster an enhanced feeling of empathy, which is an important quality in the cultivation of active citizenship. When students reflect upon moral and global questions described in literature, they may try to find the answers and engage themselves with social concerns and interests. They may further read relevant informational books, get more resources from the internet, voice their opinions on the content of texts through writing, take part in class discussions and debates, and connect the texts with themselves and the wider contexts by joining organizations of the same interest. The affective and critical power of literature can indeed challenge students' values and prompt them to become active citizens, who strive to bring about change and social justice in their community.

In this sense, literature can be integrated with service learning. Students' changed ways of seeing enable them to have more involvement in the community. Jacoby (1996) defines service learning as "a form of experiential education in which students engage in activities that address human and community needs together with structured opportunities intentionally designed to promote student learning and development. Reflection and reciprocity are key concepts of service learning" (p. 5). Service learning is therefore an experiential education approach which emphasizes reciprocal learning; that is to say, all parties involved benefit from the activities. Dewey (1963) is one of the pioneering educators to discuss the connection between learning and experience. His notion of learning as a dialectic process integrating experience and concepts, observations, and action was later synthesized by Kolb (1984) into a key component of his experiential learning theory. Kolb's model often begins with "concrete experience," which provides a basis for "reflective observation." This "reflective observation" is developed into "abstract conceptualization," which can be tested through the process of "active experimentation," which in turn creates new experiences, and the cycle continues. McEwen (1996) noted that reflection follows direct and concrete experience because for students, the most immediate experience is the affective experience of learning. This point is significant to my study, especially given that an important motivation for students to serve is their aspirations to values and humanity enlightened by reading. It is hoped that through authentic human interaction, and not just through learning concepts in books and theories, they will think more deeply about these issues and social problems. Research findings (for example, Astin et al. 2000; Colby et al. 2009) give strong evidence that service learning produces positive effects on students' cognitive and affective development.

Based upon the aforementioned theories and studies, a project was designed for students to apply what they learnt and thought about from reading to thoughtfully organized service experiences that simultaneously met community needs and stimulated students' personal and intellectual growth. Reflection in reading and service learning was emphasized so that students could develop an internalized consciousness in understanding text content, their own needs, and the situation of the people whom they served. Students would raise questions regarding social and global issues in the process of learning and then develop the ability to act on them.

\section{The project}

A "Reading and Social Service Scheme" was introduced in September 2009 to 24 freshmen of the Bachelor of Education (Chinese language and literature education) in the Faculty of Education of the University of Hong Kong. The scheme aims to encourage students to read more about society and to respond to their reflections by taking action. A particular theme for the reading will be set every year in a three-year scheme. The theme for the reading of the Year 1 students focused on children welfare, and the theme will be women welfare when they continue the scheme in Year 2. After reading the recommended translations of world literature, the students had to submit a book report and give an oral presentation in a sharing session. They then involved themselves in social service individually or in small groups, particularly in areas related to health care, education, and poverty of children. Aside from writing their reflections on service learning, the students also shared their experience in a culminating session. At the end of the first year, students compiled a portfolio as a detailed record of their personal development during the reading and service period.

The goals of the scheme are as follows:

1. Students can read in-depth publications related to social concerns through which their interdisciplinary reading abilities can be enhanced.

2. Students can develop their interest in the category of literary works they read. 
3. Students are able to reflect upon and understand others' feelings through analyzing problems from different perspectives and sincerely care about the underprivileged, especially the needs of children and women.

4. Students can accumulate their knowledge of the culture and society of different countries through reading translated literature.

5. Students can understand the literary works more thoroughly and respond to the needs of the underprivileged through participating in community service.

6. Students can explore more thoroughly the issues of poverty and injustice in Hong Kong and around the world through service learning so that they can reflect on ways to improve the poor circumstances of the underprivileged.

The scheme was implemented for one year. This paper acts as a formative assessment of the scheme by examining the results of a pre-scheme and a post-scheme questionnaire completed by the participants of the scheme. ${ }^{1}$

\section{Method \\ Participants}

All the 24 freshmen participating in the "Reading and Social Service Scheme" were invited to join the study. As mentioned above, these students were involved in a comprehensive set of activities, which included reading literary works, involving themselves in social service, writing reflective journals, and presenting their experiences in the past year. This cohort of BEd students was free to participate in this scheme, and they understood that their final grade would not be affected by their decision to participate or not. The teacher/researcher did not teach them any subjects in the first 2 years of their study.

\section{Scope of the study}

The scope of the scheme being assessed in this study was reading literary works and involvement in social service. These two activities on the theme of children affairs were introduced to the students during their first year of study.

\footnotetext{
1 This paper will not include the assessment of students' portfolios, which is substantial enough for another paper. Students have the flexibility to design their portfolios such as incorporating photographs of the service activities and letters with the children whom they served. However, they were required to put the basic materialsreading reflections and service descriptions and reflections-into the portfolio.
}

In the first semester, after reading the book A Long Way Gone: Memoirs of a Boy Soldier, which is about the issue of child soldiers in Africa, students were asked to explore and discuss the issue based on their insights gained from the book. They were also expected to write down and present their reflections. Other related nonfiction materials were provided for students' reference.

In the second semester, the students worked with 12 non-government organizations (NGO) and participated in different voluntary services for children according to their interests. Some of them joined the "School that Care for the Poor" project organized by the Mission to the New Arrivals. Some students became members of the University's China Education Association, visiting children in the rural areas of Guangdong. Some organized with Caritas a six-day activity for children from low-income families. Some joined more than one project.

\section{Questionnaires}

At the beginning and the end of the academic year, all students completed a questionnaire on their humanistic concerns and sense of global citizenship. The questionnaire, translated into English in Appendix A, was written in Chinese. Based upon the specific goals of the project, the framework of the questionnaire was developed by integrating theoretical elements proposed by various researchers in the two areas of reading and service. The importance of literary reading to citizenship (Nussbaum 1997) and the power of art (Halstead and Pike, 2006) figure prominently in the first two goals of the project but are also reflected in the other goals as well. Goals three to six reflect the significance of service learning which stems from Jacoby's (1996) seminal work. In addition, Eyler and Giles (1999) have identified and assessed the learning outcomes of service. Among the variety of outcomes, two of them-personal development and citizenship - are most pertinent to our framework. According to the above rationale, the questionnaire comprises questions about students' perceptions toward five domains: (1) changes in their attitudes and values since joining the scheme; (2) social service; (3) their participation in social service in the university; (4) their reading attitude; and (5) global concerns. Domains 2-3 respond to the goals related to service, whereas domain 4 responds to the goals related to reading. Domains 1 and 5 respond to the goals related to both areas of reading and service.

The questionnaire contained different question types: a 11-point Likert scale, a 5-point Likert scale, multiplechoice questions, and open-ended questions. Six questions were rated on the 11-point Likert Scale, ranging from 10 ("Frequently"/"Very") to 0 ("Never"/"No"), while two 
questions were rated on the 5-point Likert Scale, ranging from 4 ("Very interested") to 0 ("Not at all"). There were three multiple-choice questions and four open-ended questions. For the 11-point Likert scale and the multiplechoice questions, spaces were provided for additional comments.

\section{Data analysis}

All quantitative analyses were carried out by SPSS. The self-report ratings in the 11-point Likert scale and the fivepoint Likert scale questions were analyzed directly without codification. For the multiple-choice and open-ended questions, answers were graded according to the marking schemes attached in Appendix B. To maximize the validity of the study, this study adopted both quantitative and qualitative methods, i.e., the use of triangulation. Qualitatively, besides examining the open answers in the questionnaire, each participant's general performance in the questionnaire was cross-checked by comparing it to that of his or her oral presentation in the culminating sessions.

The marking scheme for the questionnaire is based on the theoretical framework of Bloom and his colleagues (Bloom et al. 1956) and that of Krathwohl and his colleagues (Krathwohl et al. 1974) on learning. Both Bloom et al. (1956) and Krathwohl et al. (1974) construe educational goals in hierarchical terms. In the cognitive domain, the hierarchy consists of six levels, from the lowest to the highest, namely knowledge, comprehension, application, analysis, synthesis, and evaluation. In the affective domain, the hierarchy consists of five levels, namely receiving, responding, valuing, organization, and characterization. The marking scheme of the depth of cognitive and affective learning of each participant of our questionnaire was formulated in reference to these two hierarchies. In this marking scheme, answers implying low cognitive and affective learning would yield fewer points. Examples of such include not understanding the meaning of social service, less serious reading attitude, helping people superficially, and feeling distant to the underprivileged. For answers scoring two to four points, they represented progressively deeper cognitive and affective learning, from "knowledge" to "application" in the cognitive hierarchy and from "receiving" to "valuing" in the affective hierarchy. Examples of such include making significant contribution to society through service, more interest in reading books concerning social issues, achieving growth in personal and social values, and feeling a sense of belongingness to the world. For those questionnaire items that cannot be classified according to the framework of Bloom et al. (1956) and Krathwohl et al. (1974), scores will be given according to the perceived depth of the answers. For instance, in E4, the answer of "taking part in social service programs" would be scored higher than that of "donating money or materials" because the former implies more personal involvement in helping people than the latter. In order to increase the reliability of the study, the scoring was conducted by two raters (the researchers). The degree of concordance between the two raters was sufficiently high that no inter-rater agreement test was deemed warranted. Whenever the case of an answer involving features of more than one marking level arose, a higher score would always be given to the student.

Having less than 30 cases in this study, paired-sample analysis was used to ensure adequate power to detect any effect and to avoid a type II error. According to Stevens (2002), repeated-measure analyses are statistically more powerful than a completely randomized design. The prepost-scores from the self-report ratings and the graded marks were therefore compared by paired-sample $t$-tests. ${ }^{2}$

\section{Limitation of the study}

Because there was no control group in this study, the students' changes in attitudes and values may not solely come from their participation in the project. In order to solve this problem, students were reminded to respond specifically to the scheme activities when they were filling out the postquestionnaire.

\section{Results}

The purpose of the study was to examine the benefits that students gained from the interdisciplinary program of reading literary works and participating in social services. This paper analyzed all the questions in the questionnaires as listed in the following tables.

\section{Overall changes}

In the self-assessment of change after joining the "Reading and Social Service Scheme," all the participants gave

\footnotetext{
${ }^{2}$ For a better interpretation of the above significant difference between the pre-post scores and a further examination on the statistical power of the study, power analysis was carried out on the questions with significant results. The analysis showed that all significant results (except one) with $p<0.01$ have the observed power more than 0.80 at the alpha 0.05 level. For the one below 0.80 (question C2), the observed power is 0.793 , being very close to the convention adequate power 0.80 (Cohen 1988). For the three questions having results with $p<0.05$, the observed power is between 0.55 and 0.67 , which implies a moderate power to detect the effect size. These three questions are therefore needed to be interpreted with caution.
} 
Table 1 Self-assessment of change

\begin{tabular}{lc}
\hline $\begin{array}{l}\text { Any change after joining the "Reading \& Social } \\
\text { Service Scheme"? (10= "Profound change", }\end{array}$ & $\begin{array}{l}\text { Numbers of } \\
\text { participants }\end{array}$ \\
$1=$ "No change") & \\
\hline 6 & 2 \\
7 & 13 \\
8 & 5 \\
9 & 3 \\
10 & 1 \\
Total & 24 \\
\hline
\end{tabular}

Table 2 Aspects of change

\begin{tabular}{lllc}
\hline Domain & $\begin{array}{l}\text { In what aspect have you } \\
\text { changed since joining the } \\
\text { scheme? }\end{array}$ & $\begin{array}{l}\text { Numbers of } \\
\text { participants }\end{array}$ & $\begin{array}{l}\text { Percentage } \\
(\%)\end{array}$ \\
\hline Values & $\begin{array}{l}\text { A sense of mission toward } \\
\text { helping others }\end{array}$ & 11 & 46 \\
Values & $\begin{array}{l}\text { Positive life attitude } \\
\text { Knowledge about social } \\
\text { Knowledge }\end{array}$ & 6 & 25 \\
Skills & $\begin{array}{l}\text { Problem solving } \\
\text { Total }\end{array}$ & 2 & 21 \\
& & 24 & 8 \\
\hline
\end{tabular}

positive responses. Table 1 shows that the mean score is $7.5(\mathrm{SD}=0.98)$ (with 10 as the highest score for profound change). Moreover, Table 2 shows that the changes include aspects of values, knowledge, and skills. Seventyone per cent of participants noted their change in values after joining the scheme. These students stated that their changes were in personal and social values, especially in developing respect for people, adopting more positive learning and life attitudes, and finding happiness and satisfaction in helping people. One student (S16) said, "Previously, I used excuses to refuse to do voluntary work, but now I have become very positive and have learned that it is much better to give than to take." Three students (S7, S9, and S12) stressed that as they would become teachers in the future, they could see the importance of promoting education for poor children and helping them to develop positive values. With respect to the aspect of knowledge, $21 \%$ of students reported that they had become more concerned with social issues such as child development and poverty in society. One student (S13) remarked, "I have come to understand that poverty is not just about material things." Some students (8\%) also reflected more on practical problems, such as the skills of handling sensitive questions and conducting activities.
Attitude toward serving others

As seen from Table 3, after joining the program, students showed a significant improvement in defining social service $[t(23)=-2.5, p<0.05]$ and expanded its meaning from responsibility to dedication. They explained that social service and learning were related $[t(23)=-3.21$, $p<0.00]$, and they understood that service learning was not only just about providing service, but also a process of learning, especially in developing values. Concerning the frequency of participation, the mean score was 2.04 for the past five years, i.e., when the students were in secondary schools, but the mean score was 2.33 for the first year of the university. The increase in the score for social service shows that students had been more involved in the past year.

More importantly, students rated a higher mark than before for their enthusiasm for involving themselves in social service $[t(23)=-4.60, p<0.01]$ and provided a fuller explanation for their ratings $[t \quad(23)=-2.95$, $p<0.01]$, such as having a more serious attitude toward, and giving more time to, social service. One participant (S3) noted in the pre-questionnaire, "I am not clear about what social service is and shall not take the initiative in searching for the related information." After joining the program, however, the same participant stated in the postquestionnaire, "I have become more mature and have grown spiritually. I am more actively involved in social service than before." Another participant (S11) wrote in the pre-questionnaire, "The services I have joined are limited to the church." After joining the program, this same participant commented, "I have become more active in participating in social service and now pay more attention to information about voluntary work." She also expressed similar thoughts in her oral presentation: "Before I was not very keen on doing voluntary works because I thought many were just nominal volunteers who did so only for getting a certificate or fulfilling the requirements of school extra-curricular activities. But after participating in a service program of tutoring in the past months, my attitude toward service has changed dramatically. I find that I can help the working-class people, especially school children, through tutoring. In my case, I assisted a girl's homework after school. To my surprise, the girl's mother was sitting beside us every time when I was tutoring. In our last session, the mother expressed her great appreciation for my assistance to her daughter and said that she had also learned a lot together with her. She revealed that she was a new immigrant to Hong Kong from Mainland China and did not know how to help her daughter. She felt a lot of pressure, and as a result of that, there had been a lot of clashes between them. I was deeply touched by the mother's words. In fact I have learned a lot from her too because she 
Table 3 Perception toward social service

\begin{tabular}{|c|c|c|c|c|c|c|c|}
\hline Sources & Questions & Time & $\mathrm{N}$ & Mean & SD & $t$ & $p$ \\
\hline \multirow{2}{*}{$\begin{array}{l}\text { Marking } \\
\text { scheme }\end{array}$} & \multirow[t]{2}{*}{ B1. What do you think the definition of social service is? } & Pretest & 24 & 1.88 & 0.74 & & \\
\hline & & Posttest & 24 & 2.42 & 0.72 & $-2.5^{*}$ & $0.02 *$ \\
\hline \multirow{2}{*}{$\begin{array}{l}\text { Marking } \\
\text { scheme }\end{array}$} & \multirow[t]{2}{*}{ B2. Why are social service and learning related? } & Pretest & 24 & 3.04 & 1.08 & & \\
\hline & & Posttest & 24 & 3.75 & 0.44 & $-3.21 * *$ & $0.00 * *$ \\
\hline \multirow[t]{2}{*}{ Self-report } & \multirow[t]{2}{*}{ B4. Rate your attitude toward participating in social service in the past year. } & Pretest & 24 & 5.63 & 1.61 & & \\
\hline & & Posttest & 24 & 7.17 & 0.92 & $-4.60 * *$ & $0.00^{* *}$ \\
\hline \multirow{2}{*}{$\begin{array}{l}\text { Marking } \\
\text { scheme }\end{array}$} & \multirow[t]{2}{*}{ B4. Explain the above rating. } & Pretest & 24 & 2.21 & 1.35 & & \\
\hline & & Posttest & 24 & 3.25 & 1.15 & $-2.95 * *$ & $0.01 * *$ \\
\hline \multirow{2}{*}{$\begin{array}{l}\text { Marking } \\
\text { scheme }\end{array}$} & \multirow{2}{*}{$\begin{array}{l}\text { B5. What are the three most rewarding things after participating in social } \\
\text { service? (total marks from the three answers) }\end{array}$} & Pretest & 24 & 5.54 & 2.83 & & \\
\hline & & Posttest & 24 & 6.88 & 2.40 & $-3.14 * *$ & $0.00^{* *}$ \\
\hline
\end{tabular}

$* p<0.05, * * p<0.01$

made me become more sensitive to the needs of people. Now, I truly think that I can help people through my knowledge and my heart."

Students' reflections on the outcomes after doing social service had improved remarkably. The improvement is significant because their reflections focused more than before on a change in personal and social values (scored 4 marks according to the marking scheme) $[t(23)=-3.14$, $p<0.01]$. For instance, in the pre-questionnaire, one participant (S1) said that in general, her two biggest rewards after doing social service were "having a sense of achievement" and "getting wide experiences," while in the post-questionnaire, this same participant wrote that the most rewarding things were "learning to give," "learning how to respect others," and "caring about people and understanding their feelings." Another participant (S3) reported in the pre-questionnaire that the rewarding things were "knowing people from different walks of life" and "knowing my strengths and making a contribution to society." In the post-questionnaire, this same participant said, "I understand what 'spiritual poverty' means, know more mentally handicapped children whom I had not had contact with before, and I have started to reflect seriously on my attitude toward life." To conclude, the students explicitly expressed their personal and interpersonal development.
The 24 students maintained their interest in obtaining information about social service during their study in the university. Table 4 indicates that since joining the program, students had become more positive about doing social service, and they gave more concrete answers in explaining their plan of service $[t(23)=-2.90, p<0.01]$. In reference to the marking scheme of this question, this significant result implied that students were more aware of the needs of the underprivileged. They were also more engaged and compassionate in helping others because they enjoyed the satisfaction gained. One participant (S10) said in the pre-questionnaire, "Learning should not be limited to the classroom." In the post-questionnaire, this same participant said, "I would like to maintain continuous friendship with the children whom I served." Another participant (S5) left the part about the reason for her doing social service blank in the pre-questionnaire, but in the post-questionnaire, said, "I love helping people and care about those who are in need." The findings show that the sustainability of their work was due to increasingly positive outlooks and values.

Engagement in reading literary works

Overall, the mean of reading frequency was still not high (less than 5 on a scale of 11 points), but students were

Table 4 Participation in social services in the university

\begin{tabular}{|c|c|c|c|c|c|c|c|}
\hline Sources & Questions & Time & $\mathrm{N}$ & Mean & SD & $t$ & $p$ \\
\hline \multirow{2}{*}{$\begin{array}{l}\text { Self- } \\
\text { report }\end{array}$} & \multirow{2}{*}{$\begin{array}{l}\text { C1. Are you interested in obtaining information about social service in the } \\
\text { University of Hong Kong? }\end{array}$} & & 24 & 2.92 & 0.28 & & \\
\hline & & Posttest & 24 & 3.04 & 0.55 & -1.00 & 0.33 \\
\hline \multirow{2}{*}{$\begin{array}{l}\text { Marking } \\
\text { scheme }\end{array}$} & \multirow{2}{*}{$\begin{array}{l}\text { C2. Why are you planning/not planning to participate in social service in the } \\
\text { university in the coming } 4 \text { years? ( } 3 \text { years for post-questionnaire) }\end{array}$} & & 24 & 1.92 & 1.84 & & \\
\hline & & Posttest & 24 & 3.08 & 1.21 & $-2.90 * *$ & $0.01 *$ \\
\hline
\end{tabular}

$* p<0.05, * * p<0.01$ 
Table 5 Reading Attitude

\begin{tabular}{|c|c|c|c|c|c|c|c|}
\hline Sources & Questions & Time & $\mathrm{N}$ & Mean & SD & $t$ & $p$ \\
\hline \multirow[t]{2}{*}{ Self-report } & \multirow{2}{*}{$\begin{array}{l}\text { D1. How often do you read books or magazines concerning social issues in } \\
\text { Hong Kong or worldwide? }\end{array}$} & Pretest & 24 & 4.42 & 1.72 & & \\
\hline & & Posttest & 24 & 4.88 & 2.09 & -1.07 & 0.30 \\
\hline \multirow{2}{*}{$\begin{array}{l}\text { Marking } \\
\text { scheme }\end{array}$} & \multirow{2}{*}{$\begin{array}{l}\text { D2. What literary or non-literary books concerning social issues in Hong Kong } \\
\text { or worldwide do you read? }\end{array}$} & Pretest & 24 & 0.96 & 1.37 & & \\
\hline & & Posttest & 24 & 2.58 & 1.69 & $-3.43 * *$ & $0.00 * *$ \\
\hline \multirow{2}{*}{$\begin{array}{l}\text { Marking } \\
\text { scheme }\end{array}$} & \multirow{2}{*}{$\begin{array}{l}\text { D2. What kinds of magazines concerning social issues in Hong Kong or } \\
\text { worldwide do you read? }\end{array}$} & Pretest & 24 & 0.96 & 1.43 & & \\
\hline & & Posttest & 24 & 1.25 & 1.51 & -1.13 & 0.27 \\
\hline \multirow[t]{2}{*}{ Self-report } & \multirow[t]{2}{*}{ D3. Are you interested in reading more of the aforementioned publications? } & Pretest & 24 & 2.79 & 0.59 & & \\
\hline & & Posttest & 24 & 3.04 & 0.36 & -1.66 & 0.11 \\
\hline
\end{tabular}

$* p<0.05, * * p<0.01$

developing their interest in reading multicultural books that reflected social and moral issues in different parts of the world. Table 5 shows that after joining the program, students pointed out a significantly wider range of books related to social issues in Hong Kong or worldwide $[t(23)=-3.43, p<0.01]$. Some books that the students mentioned are The Kite Runner, A Thousand Splendid Suns, Three Cups of Tea, and The Diary of Anne Frank. They also paid more attention to information about social service from websites and newsletters of local NGOs. In the oral presentation, a group of students produced a PowerPoint presentation on the problem of child soldiers in Myanmar and Uganda and said: "After reading the book and collecting information on this issue, we have learned a lot more concrete information about the miserable situation of child soldiers in the world. When we are little, we should be playing and enjoying our childhood. But many children in different parts of the world are actually living in fear and terror. The guns are their toys. They frequently kill people and are themselves getting killed. Our help to them may be limited, but we should keep ourselves informed of this issue. We admire the three university students who went to Uganda to make the video 'The Invisible Children' which highlighted the plight of Ugandan children during the civil war there. We would also financially support the campaigns and organizations that aim at solving the problem of child soldiers."

Attention to world affairs and concern for the underprivileged

Table 6 shows the significant improvement of students in their concern for the world $[t(23)=-3.33, p<0.01]$, and the more reflective answers the students provided to support their ratings $[t(23)=-2.17, p<0.05]$. One participant

Table 6 Global concern

\begin{tabular}{|c|c|c|c|c|c|c|c|}
\hline Sources & Questions & Time & $\mathrm{N}$ & Mean & SD & $t$ & $p$ \\
\hline \multirow{2}{*}{$\begin{array}{l}\text { Self- } \\
\text { report }\end{array}$} & \multirow[t]{2}{*}{ E1. Rate your concern with world affairs. } & Pretest & 24 & 6.13 & 1.19 & & \\
\hline & & Posttest & 24 & 7.02 & 1.81 & $-3.33 * *$ & $0.00 * *$ \\
\hline \multirow{2}{*}{$\begin{array}{l}\text { Marking } \\
\text { scheme }\end{array}$} & \multirow[t]{2}{*}{ E1. Explain the above rating. } & Pretest & 24 & 2.58 & 1.41 & & \\
\hline & & Posttest & 24 & 3.17 & 1.20 & $-2.17 *$ & $0.04 *$ \\
\hline \multirow{2}{*}{$\begin{array}{l}\text { Self- } \\
\text { report }\end{array}$} & \multirow[t]{2}{*}{ E2. Rate your concern about the underprivileged in the world. } & Pretest & 24 & 6.42 & 1.10 & & \\
\hline & & Posttest & 24 & 6.96 & 1.57 & -2.07 & 0.05 \\
\hline \multirow{2}{*}{$\begin{array}{l}\text { Marking } \\
\text { scheme }\end{array}$} & \multirow[t]{2}{*}{ E2. Explain the above rating. } & Pretest & 24 & 1.79 & 1.18 & & \\
\hline & & Posttest & 24 & 2.67 & 0.87 & $-3.14 * *$ & $0.00 * *$ \\
\hline \multirow{2}{*}{$\begin{array}{l}\text { Self- } \\
\text { report }\end{array}$} & \multirow[t]{2}{*}{ E3. Have you thought about helping the underprivileged in the world? } & Pretest & 24 & 6.29 & 1.30 & & \\
\hline & & Posttest & 24 & 7.08 & 1.35 & $-2.44 *$ & $0.02 *$ \\
\hline \multirow{2}{*}{$\begin{array}{l}\text { Marking } \\
\text { scheme }\end{array}$} & \multirow[t]{2}{*}{ E3. Explain the above rating. } & Pretest & 24 & 1.96 & 1.20 & & \\
\hline & & Posttest & 24 & 2.79 & 1.02 & $-3.05 * *$ & $0.01 * *$ \\
\hline \multirow{2}{*}{$\begin{array}{l}\text { Marking } \\
\text { scheme }\end{array}$} & \multirow{2}{*}{$\begin{array}{l}\text { E4. Do you have any ways of relieving the suffering of the underprivileged in the } \\
\text { world? (total marks from the three answers) }\end{array}$} & Pretest & 24 & 6.29 & 3.52 & & \\
\hline & & Posttest & 24 & 7.92 & 3.53 & -1.95 & 0.06 \\
\hline
\end{tabular}

$* p<0.05, * * p<0.01$ 
(S2) said in the pre-questionnaire, "I seldom pay attention to world affairs because I think that they are too far away from Hong Kong." However, in the post-questionnaire, the same participant stated, "I am more concerned with world affairs than before because after doing social service, I understand that the affairs in other places are very serious." Another participant (S19) wrote in the pre-questionnaire, "I am always interested in things in my society, and world issues seem too distant to me." In the post-questionnaire, the same participant wrote, "The world is a whole, and everything happening in the world is related to us." These students had expanded their horizons.

Students also gave more thoughtful reasons for their concern about the underprivileged in the world $[t(23)=-$ $3.14, p<0.01]$. They expressed their sympathy for them, showed their concern with social justice, and thought that they had a sense of belongingness to the world. One of the participants (S12), who had left the answer blank in the pre-questionnaire, stated in the post-questionnaire, "The unfortunate experiences of the underprivileged keep reminding me to appreciate what I have. Under the same sky, their misfortunes are the whole world's misfortunes." Another participant (S6) wrote in the pre-questionnaire, "I saw my fortune in their misfortune." In the post-questionnaire, however, he said, "I am concerned about those underprivileged because of compassion and justice. There is too much injustice in the world." From the two questions above, we can see that in the learning process of global concern, both the cognitive and affective aspects of students had been developed.

Awareness of the potential in helping the poor

After participating in the program, students were more aware of their potential in helping the needy. As indicated in Table 6, there was a significant increase in students' motivation to help the needy in the world $[t(23)=-2.44$, $p<0.05]$. Students elucidated their motivation with more in-depth explanations $[t(23)=-3.05, p<0.01]$. They hoped to relieve the suffering of the poor and give comfort to them. One student (S19) left this part blank in the prequestionnaire but said in the post-questionnaire, "We are all humans and should have a heart of mercy." She hoped that she could assist NGOs in supporting the lives of children and help in advocacy works. Another participant (S10) said in the pre-questionnaire, "Because I am prosperous, I hope to help those in need." In the post-questionnaire, this same participant said, "Those miserable people are also members of the global village, so we should share our love with them." She hoped to teach children in poor areas and visit Cambodia through experiential trips. Other students also suggested concrete ways to help people, such as joining visits organized by NGOs, keeping in contact with the children whom they had served, and writing articles about social problems in the mass media. S12, the student mentioned in the above section, said in the oral presentation: "University students are a very privileged group of people in society and I am one of them. I think we owe society something. By virtue of my belief and strength, I would like to help children who lack learning opportunities in rural China. Besides financial support, I would like to be personally involved in this issue. Now I have become a member of the University's China Education Association and I am working with my team to develop projects that aim at improving rural education in China." To conclude, many students' concern was being transformed into actions.

To summarize the results, the quantitative and descriptive data showed that students were conscious of how they had changed in attitudes and values since joining the program. The paired-sample $t$-test analysis suggested that the "Reading and Social Services Scheme" had significantly improved students' cognitive and affective growth in the following five domains: (1) their attitude toward serving others, especially in their personal and social values; (2) their engagement in reading literary and nonfiction works that reflect social and moral issues of the world; (3) their attention to world affairs; (4) their concern for the underprivileged; and (5) awareness of their potential in helping the poor. Their changes can be reflected in their self-assessment and actual performance of reading and serving.

\section{Discussion}

The project achieved its goals of developing students' humanistic concerns and sense of global citizenship. Students showed cognitive and affective growth in understanding themselves, society, and the world by internalizing what they learned about the meaning of life and citizenship through the interdisciplinary program of reading and service learning. In response to the theme of the scheme in the past year, students demonstrated their enthusiasm for helping children in need. They showed their sincere feelings toward the people whom they served and gave comments on social problems in the presentations, portfolios, and questionnaires.

The most valuable part of the project was that they were conscious of their changes in personal efficacy. As Eyler and Giles (1999) points out, the impact of service learning on personal growth and development include self-knowledge, spiritual growth, and satisfaction in helping others. Affectively, service learning had fostered in them a stronger sense of caring for the underprivileged and an understanding of the need to pursue more justice in the 
world. Cognitively, students had increased their concern with world affairs and social problems, as well as an awareness of their potential for helping the poor. Students' horizons were broadened; for instance, they paid special attention to the issue of child soldiers in Africa, as this was the theme of the book A Long Way Gone, which had to be reported on in the reading session. The advantage of this single-book model in the presentation was that students could have a common ground for in-depth discussion on one topic, but the disadvantage was that they were not exposed to a wide scope of global issues in their reading. Therefore, in the second stage of the project, a wider range of books were recommended to them for the reading activity. It is expected that students can share more information obtained from one another in the session through the multiple-books model.

Students' engagement in reading across the curriculum, which deals with the themes of multicultural understanding as well as social and moral concerns, had been heightened. The books that the students read were more global than before and reflected social and moral issues in different parts of the world. This was a great improvement for the students as the content of books the students read has extended from local to global issues since joining the program. However, when considering that the services that the "Reading and Social Learning program" introduced were mainly local, there seemed to be a gap between their reading of world literature and its relevance to their participation in local community service. It could be argued that no matter in what countries, most children's problems are related to poverty. In this project, students would like to foster a change in the way citizens perceive poverty in Hong Kong and Mainland China. However, the literary works they read were from all over the world and multicultural, while the concrete service experiences took place mainly in Chinese-speaking areas. Gaps between global and local concerns, multicultural and monocultural experiences, were evident. Therefore, in the second stage of the project, socially related Hong Kong literature and non-literary materials were added to the reading list; students were encouraged to participate not only in local activities, but also in overseas experiential trips organized by the University and non-government institutions. Another suggestion is that students can offer services to ethnic minority groups in Hong Kong, who in turn can share their cultures with the students. In this way, students can bridge the credibility gap between thought and action by helping to enhance the lives of the underprivileged at home and abroad.

In the past year, the 24 students participated in different voluntary services for children according to their interests. During this stage, they explored their passionate interests and expected support from the relevant organizations. Although the $t$-test analysis showed that the students' thoughts concerning the most rewarding things in doing social service had become more reflective and more focused on social and personal values, the review of student portfolios implied that there was still room for improvement. Most students merely displayed photographs or reported their tasks in detail in the portfolios, rather than setting down their feelings and comments during the community engagement activities. According to the results of the first assessment, it would be better if more training and guidance were provided to the students. Faculty members and instructors of volunteer agencies could administer more detailed briefings before the service, encourage continuous and serious reflection exercises during the learning experiences, and help students generalize valuable concepts in order to make the service more meaningful for them.

The project is still ongoing, and the 24 students are making significant improvements. It is hoped that this kind of interdisciplinary program of reading and service learning can inspire more young people in secondary schools and universities to become empowered citizens. Karsten et al. (2002) in particular have stressed the importance of citizenship education to future teachers who will have to teach young people. This study serves as a reference for educators to draw up a comprehensive reading and service learning program. In this way, students and teachers can realize the power and possibilities offered by literature and citizenship education that can contribute to local and global communities in improving humanity and social justice.

Open Access This article is distributed under the terms of the Creative Commons Attribution Noncommercial License which permits any noncommercial use, distribution, and reproduction in any medium, provided the original author(s) and source are credited.

\section{Appendix 1: "Reading and Social Service Scheme" Questionnaire}


"Reading and Social Service Scheme" Questionnaire

(A) General

1. Have you changed your attitude towards social service since joining the "Reading and Social Service Scheme"? (post-questionnaire only)

No change Profound change In what aspect?

(B) Social Service

1. What do you think the definition of social service is?

2. Are social service and learning related?

$\square \quad$ No ideas

口 Not related

ㅁ Related, reasons:

3. List the social services that you have participated in during the past year (in the past 5 years for pre-questionnaire):

\begin{tabular}{|c|c|c|}
\hline Dates & Details & Organizations \\
\hline \hline & & \\
\hline & & \\
\hline
\end{tabular}

4. Rate your attitude towards participating in social service in the past year. Indifferent

Reasons:

5. What are the most rewarding things after participating in social service? (List the most first, not necessary to fill in all the blanks)

A.

B.

C.

(C) University

1. Are you interested in obtaining information about social service in the University of Hong Kong?

$$
\begin{aligned}
& \text { Not at all } \\
& \begin{array}{|c|c|c|c|c|}
\multicolumn{3}{c}{\text { Very interested }} \\
\hline 0 & 1 & 2 & 3 & 4 \\
\hline
\end{array}
\end{aligned}
$$

2. Are you planning to participate in social service in the university in the coming 4 years? (3 years for post-questionnaire)

$\square$ Yes, reasons:

Social service programmes you plan to participate in:

口 Have not thought about it

$\square$ No

(D) Reading

1. How often do you read books and magazines concerning social issues in Hong Kong or worldwide (such as problems related to poverty, war, hunger, AIDs, disability, gender inequality, racial discrimination, drug abuse, child prostitution, and the elderly)?

Never

Frequently

2. What literary and non-literary books and magazines concerning social issues in Hong Kong or worldwide do you read?

A. Books:

B. Magazines (such as newsletters from NGOs, community centers, and religious groups):

3. Are you interested in reading more of the aforementioned publications?

Not at all
\begin{tabular}{|c|c|c|c|c|}
\hline 0 & 1 & 2 & 3 & 4 \\
\hline
\end{tabular}

(E) The World

1. Rate your concern with world affairs.

Not concerned

\begin{tabular}{|c|c|c|c|c|c|c|c|c|c|c|}
0 & 1 & 2 & 3 & 4 & 5 & 6 & 7 & 8 & 9 & 10 \\
\hline
\end{tabular}

2. Rate your concern about the underprivileged in the world

Not concerned

Reasons:

3. Have you thought about helping the underprivileged in the world? Never

Never
\begin{tabular}{|c|c|c|c|c|c|c|c|c|c|c|} 
Great \\
0 & 1 & 2 & 3 & 4 & 5 & 6 & 7 & 8 & 9 & 10 \\
\hline
\end{tabular}

Reasons:

4. Do you have any ways of relieving the suffering of the underprivileged in the world?

口 No ideas

$\square$ Have thought of the following suggestions:

A.

B. 


\section{Appendix 2}

See Table 7.

Table 7 Marking Scheme

\begin{tabular}{|c|c|c|c|c|c|}
\hline Marks & 0 & 1 & 2 & 3 & 4 \\
\hline \multicolumn{6}{|l|}{ B. Social Service } \\
\hline $\begin{array}{l}\text { B1. What do you think the definition } \\
\text { of social service is? }\end{array}$ & Blank & Responsibility & $\begin{array}{l}\text { Helping others/ } \\
\text { solving social } \\
\text { problems }\end{array}$ & $\begin{array}{l}\text { Contribution to } \\
\text { society }\end{array}$ & $\begin{array}{l}\text { Dedication to } \\
\text { others \& self- } \\
\text { development }\end{array}$ \\
\hline $\begin{array}{l}\text { B2. Why are social service and } \\
\text { learning related? }\end{array}$ & Blank & Not related & $\begin{array}{l}\text { Need to learn before } \\
\text { providing social } \\
\text { services (e.g. } \\
\text { professional } \\
\text { qualification) }\end{array}$ & $\begin{array}{l}\text { Apply things } \\
\text { learnt to social } \\
\text { services/have } \\
\text { gains }\end{array}$ & $\begin{array}{l}\text { Learn from doing } \\
\text { social services \& } \\
\text { have growth in } \\
\text { values }\end{array}$ \\
\hline $\begin{array}{l}\text { B4b. Explain your rating on your } \\
\text { attitude toward doing social } \\
\text { service. }\end{array}$ & Blank & $\begin{array}{l}\text { Do not understand the } \\
\text { meaning of social } \\
\text { service }\end{array}$ & $\begin{array}{l}\text { Do not take part in } \\
\text { social service } \\
\text { actively (e.g. no } \\
\text { time) }\end{array}$ & $\begin{array}{l}\text { Have } \\
\text { improvement/ } \\
\text { hope to learn } \\
\text { more }\end{array}$ & $\begin{array}{l}\text { Take part in social } \\
\text { service actively } \\
\text { with enthusiasm/ } \\
\text { find happiness }\end{array}$ \\
\hline $\begin{array}{l}\text { B5. What are the most rewarding } \\
\text { things after participating in social } \\
\text { service? }\end{array}$ & Blank & $\begin{array}{l}\text { Become more } \\
\text { experienced \& } \\
\text { mature }\end{array}$ & $\begin{array}{l}\text { Understand how to } \\
\text { help others \& what } \\
\text { others need }\end{array}$ & $\begin{array}{l}\text { Gain satisfaction } \\
\text { from helping } \\
\text { others }\end{array}$ & $\begin{array}{l}\text { Growth in } \\
\text { personal \& } \\
\text { social values }\end{array}$ \\
\hline \multicolumn{6}{|l|}{ C. Plan in the University } \\
\hline $\begin{array}{l}\text { C2a. Why are you planning/not } \\
\text { planning to participate in social } \\
\text { service in the university in the } \\
\text { coming } 4 \text { years? (3 years for post- } \\
\text { questionnaire) }\end{array}$ & $\begin{array}{r}\text { Have not } \\
\text { thought } \\
\text { about it }\end{array}$ & $\begin{array}{l}\text { Want to broaden my } \\
\text { horizons and enrich } \\
\text { myself/do not want to } \\
\text { focus on study only }\end{array}$ & $\begin{array}{l}\text { Think that I am } \\
\text { capable/I have } \\
\text { responsibility }\end{array}$ & $\begin{array}{l}\text { Gain satisfaction } \\
\text { from helping } \\
\text { others \& feel } \\
\text { the needs of } \\
\text { others }\end{array}$ & $\begin{array}{l}\text { Hope to help } \\
\text { others }\end{array}$ \\
\hline \multicolumn{6}{|l|}{ D. Reading } \\
\hline $\begin{array}{l}\text { D2a. What kinds of books concerning } \\
\text { social issues in Hong Kong or } \\
\text { worldwide do you read? }\end{array}$ & Blank & Other leisure books & $\begin{array}{l}\text { Books about Hong } \\
\text { Kong issues }\end{array}$ & $\begin{array}{l}\text { Books about } \\
\text { China issues }\end{array}$ & $\begin{array}{l}\text { Books about } \\
\text { world issues }\end{array}$ \\
\hline $\begin{array}{l}\text { D2b. What kinds of magazines } \\
\text { concerning social issues in Hong } \\
\text { Kong or worldwide do you read? }\end{array}$ & Blank & Other magazines & $\begin{array}{l}\text { Magazines about } \\
\text { Hong Kong issues }\end{array}$ & $\begin{array}{l}\text { Magazines about } \\
\text { China issues }\end{array}$ & $\begin{array}{l}\text { Magazines about } \\
\text { world issues }\end{array}$ \\
\hline \multicolumn{6}{|l|}{ E. The World } \\
\hline $\begin{array}{l}\text { E1b. Explain the rating on your } \\
\text { concern with world affairs. }\end{array}$ & Blank & $\begin{array}{l}\text { Do not have a chance } \\
\text { to be exposed to } \\
\text { world issues/feel } \\
\text { indifferent to world } \\
\text { issues }\end{array}$ & Broaden my horizons & $\begin{array}{l}\text { Have concern } \\
\text { with the world } \\
\text { because of } \\
\text { responsibility }\end{array}$ & $\begin{array}{l}\text { Have a strong } \\
\text { feeling of being } \\
\text { part of the world }\end{array}$ \\
\hline $\begin{array}{l}\text { E2b. Explain the rating on your } \\
\text { concern about the underprivileged } \\
\text { in the world. }\end{array}$ & Blank & $\begin{array}{l}\text { Feel helpless or distant } \\
\text { to those people/do } \\
\text { not understand their } \\
\text { situation }\end{array}$ & $\begin{array}{l}\text { Think that I } \\
\text { am fortunate/pay } \\
\text { attention to their } \\
\text { needs }\end{array}$ & $\begin{array}{l}\text { Express } \\
\text { sympathy for } \\
\text { others }\end{array}$ & $\begin{array}{l}\text { Think that all are } \\
\text { equal/feel a } \\
\text { sense of } \\
\text { belongingness to } \\
\text { the world }\end{array}$ \\
\hline $\begin{array}{l}\text { E3b. Have you thought about helping } \\
\text { the underprivileged in the world? }\end{array}$ & Blank & $\begin{array}{l}\text { Feel helpless/get no } \\
\text { time to contact them }\end{array}$ & $\begin{array}{l}\text { Think that I am } \\
\text { capable/I have } \\
\text { responsibility }\end{array}$ & $\begin{array}{l}\text { Want to give } \\
\text { warmth and } \\
\text { help to them/ } \\
\text { relieve their } \\
\text { suffering }\end{array}$ & $\begin{array}{l}\text { Believe that there } \\
\text { should be love } \\
\text { and happiness in } \\
\text { the world }\end{array}$ \\
\hline $\begin{array}{l}\text { E4. Do you have any ways of } \\
\text { relieving the suffering of the } \\
\text { underprivileged in the world? }\end{array}$ & Blank & $\begin{array}{l}\text { Do not have the ability } \\
\text { to help them }\end{array}$ & Understand the issues & $\begin{array}{l}\text { Donate money or } \\
\text { materials }\end{array}$ & $\begin{array}{l}\text { Take part in social } \\
\text { service } \\
\text { programmes }\end{array}$ \\
\hline
\end{tabular}




\section{References}

Astin, A. W., Vogelgesang, L. J., Ikeda, E. K., \& Yee, J. A. (2000). How service learning affects students. Los Angeles: Higher Education Research Institute, University of California.

Bloom, B. S., Engelhart, M. D., Furst, E. J., Hill, W. H., \& Krathwohl, D. R. (1956). Taxonomy of educational objectives: The classification of educational goals. Handbook I: Cognitive domain. New York: Longmans, Green \& Co.

Chinese YMCA of Hong Kong (2010). A survey on world citizenship. Hong Kong: Chinese YMCA. Survey summary to the media.

Cohen, J. (1988). Statistical power analysis for the behavioral sciences. Hillsdale, NJ: Lawrence Erlbaum.

Colby, S., Bercaw, L., Clark, A. M., \& Galiardi, S. (2009). From community service to service-learning leadership: a program perspective. New Horizons in Education, 57(3), 20-31.

Dewey, J. (1963). Experience and education. New York: Collier Books.

Eyler, J., \& Giles, D. (1999). Where's the learning in servicelearning? San Francisco: Jossey-Bass.

Halstead, J. M., \& Pike, M. A. (2006). Citizenship and moral education: Values in action. Oxon: Routledge.

Jacoby, B. (1996). Service learning in today's higher education. In B. Jacoby \& Associates (Eds.), Service-learning in higher education: Concepts and practices. (pp. 3-25). San Francisco: Jossey-Bass.

Karsten, S., Cogan, J. J., Grossman, D. L., Liu, M. H., \& Pitiyanuwat, S. (2002). Citizenship education and the preparation of future teachers: A study. Asia Pacific Education Review, 3(2), 168-183.

Kolb, D. A. (1984). Experiential learning: Experience as the source of learning and development. Englewood Cliffs, NJ: PrenticeHall.

Krathwohl, D. R., Bloom, B. S., \& Masia, B. B. (1974). Taxonomy of educational objectives: The classification of educational goals. Handbook II: Affective domain. New York: David McKay Company.

McEwen, M. K. (1996). Enhancing student learning and development through service learning. In B. Jacoby \& Associates (Eds.), Service-learning in higher education: Concepts and practices. (pp. 53-91). San Francisco: Jossey-Bass.

Nussbaum, M. C. (1997). Cultivating humanity: A classical defense of reform in liberal education. Massachusetts: Harvard University Press.

Stevens, J. (2002). Applied multivariate statistics for the social sciences. Hillsdale, NJ: Lawrence Erlbaum.

Vacca, R. T., \& Vacca, J. A. L. (2005). Content area reading: Literacy and learning across the curriculum. Boston: Pearson. 